\title{
PLUTARCO - CONTOS DE AMOR
}

Tradução, introdução e notas de Maria Aparecida de Oliveira Silva ${ }^{1}$

\section{INTRODUÇÃo}

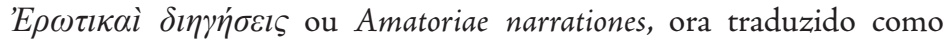
Contos de amor é um tratado cuja autoria é questionada pelo mais importante estudioso da obra plutarquiana do século passado Konrat Ziegler (1951, col. 797). O filólogo alemão argumenta que o estilo do tratado não corresponde à escrita elegante de Plutarco, e serve-se ainda do trabalho de Volkmann (1870, p. 126ss) para afirmar que se trata de um tratado indigno de Plutarco. Ziegler apoia-se também no prefácio da tradução de Volkmann feito por Hubert, quando este contesta sua autoria tendo como argumento principal o conto sobre Cedaso e suas filhas ter um enredo diferente do apresentado na Vida de Pelópidas, XX-XIV.

A despeito disso, Giangrande (1991, pp. 273-294) analisou vários tratados plutarquianos vistos como espúrios por filólogos dos séculos XIX e XX, dentre os quais está Contos de amor, e conclui pela autoria de Plutarco após refutar os argumentos que se centram no estilo e contradições narrativas. De fato, Plutarco apresenta contradiçóes em alguns episódios narrados nas biografias e nos tratados por conta da diferença de finalidade dessas obras. As biografias destinam-se a registros de eventos privados e públicos de uma personagem notável, já os tratados resultam de aulas que Plutarco ministrava em Roma e no Sul da Itália ${ }^{2}$, que tinham um caráter mais informal. Podemos ainda atribuir tais contradições a diferentes versões de uma anedota, de um mito ou de um fato histórico no mundo antigo. Por se tratar de apresentações públicas, as aulas expositivas poderiam trazer um conteúdo anedótico que melhor aprouvesse aos seus ouvintes. Lembremos, por exemplo, o caso de Helena que tem seu mito contado de várias formas, ora a bela espartana teria ido a Troia viver ao lado de Páris, conforme lhe fora prometido por Afrodite, ora teria ido ao Egito e se hospedado na corte de Proteu, por um ardil de Hera.

1 Pesquisadora do Grupo Heródoto/Unifesp e do Grupo Taphos/MAE/USP e Líder do Grupo CNPq Labhan/Ufpi.

2 Sobre essa questão, consultar: SILVA, 2006. 
Contos de amor é o tratado número 222 do Catálogo de Lâmprias ${ }^{3} \mathrm{e}$

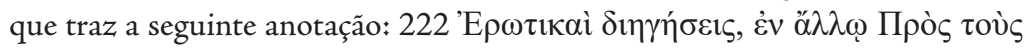

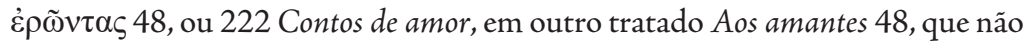
chegou aos nossos dias. Quanto à sua datação, segundo Jones (1996, p. 6), este tratado provavelmente foi escrito por Plutarco no último decênio de sua vida, cerca de 115 d.C. De acordo com Flower (1936, p. 3), embora o tratado não corresponda exatamente ao estilo de Plutarco, aborda uma temática bastante recorrente em sua época, e que provavelmente trata-se de um escrito resultante do registro de um de seus alunos. De fato, ao lermos Contos de amor e o tratado anterior Diálogo do amor, notamos que Plutarco destaca em ambos o poder de Eros, mas com algumas diferenças. Em Diálogo do amor, nosso autor elabora um discurso defendendo Eros como o deus do amor (755D-756D), enquanto, em Contos de amor, o deus não é citado diretamente, mas pode-se inferir o castigo enviado aos que tolheram o desejo dos amantes, em geral, castigados com a dor da perda.

Plutarco ressalta a impotência dos mortais diante dos desígnios de Eros, pois este é soberano nos assuntos do amor e não há razão humana que o detenha. É no entusiasmo amoroso que a presença de Eros se faz notar:

Digo, em suma, que o entusiasmo dos amantes não existe sem um deus e que não há outro deus mais primordial, fiável e condutor que esse, a quem agora festejamos e ofertamos sacrifícios. ${ }^{4}$

(PLUTARCO, Diálogo do amor, 759D) ${ }^{5}$

Plutarco chama a atenção para que "observemos [...] sua bondade e sua graça aos homens" (762B), que Eros “vai certeiro em direção à virtude" (758A),

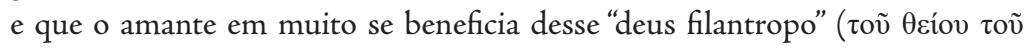

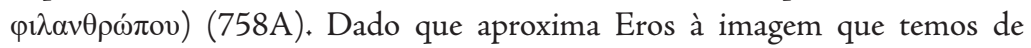

$3 \mathrm{O}$ título de cada tratado, não do conjunto da obra, foi atribuído por Lâmprias. Sobre sua origem, Flacelière e Irigoin (1987: CCI), no Apêndice de seu longo estudo acerca da obra plutarquiana, que compõe a "Introdução à Edição da Tradução Francesa dos Tratados Morais", informam que a primeira menção ao Catálogo de Lâmprias é encontrada no Suda ( $\lambda 96$ Adler) cujo autor é apresentado como sendo filho de Plutarco. No entanto, como notou Lamberton, no tratado Do Declínio dos Oráculos, Lâmprias é identificado como seu irmão, e, como o próprio autor ressalta, a datação do Catálogo de Lâmprias é desconhecida pelos estudiosos, o que, em nosso entendimento, explica as divergências sobre o grau de parentesco de Lâmprias em relação a Plutarco. Da mesma forma, lembra que Lâmprias era o nome de seu avô e de seu irmão (Assuntos de Banquetes 617E e 668D). Ressalte-se que não há qualquer referência sobre Lâmprias como sendo seu filho na obra plutarquiana (2001, p. 103).

4 Trata-se das Erotídias, um festival realizado a cada quatro anos, na cidade de Téspias, aos pés do Monte Hélicon, a morada das Musas.

5 Tradução de Maria Aparecida de Oliveira Silva (2015). 
Prometeu, igualmente chamado de filantropo ${ }^{6}$, amigo dos humanos, por ter roubado os deuses e dado à raça humana o fogo e o conhecimento das artes técnicas. Assim, com o qualificativo de filantropo, Plutarco acentua a imagem platônica de que Eros favorece a espécie humana, um deus benevolente e generoso ${ }^{7}$, por concorrer para a sua continuidade. Em Diálogo do amor, Plutarco constrói um discurso para edificar a imagem de Eros como um deus soberano e virtuoso, que excele diante dos demais, para defender Eros como o deus do amor. Tal concepção demonstra a independência do pensamento plutarquiano em relação ao platônico, uma vez que o filósofo ateniense trata Eros como uma divindade ou nume, daímōn ( $\delta \alpha \dot{\mu} \mu \omega v)$ (PLATÃO, Banquete, $202 \mathrm{~d})$, não como um deus, theós ( $\theta \varepsilon$ cós) na relação amorosa.

Em Contos de amor, Plutarco amplia o poder de Eros, antes circunscrito aos amantes em Diálogo do amor, e o estende aos agentes históricos, o que lhe confere o poder de interferir no curso da história como punição aos que ousaram desafiar os seus desígnios, pois é Eros que determina quem será o amante e o seu amado. Outro aspecto interessante do presente tratado é a ênfase dada ao amor erótico, o desejo desmedido é protegido pelo deus. $\mathrm{O}$ amor erótico é um aspecto que também se manifesta no tratado Diálogo de amor através do forte desejo que há entre Bácon e Ismenodora. Estes deixam para trás parentes e amigos contrários ao enlace quando Ismenodora planeja e executa seu rapto e Bácon se deixa raptar, evento que culmina no casamento dos amantes.

Os cinco breves contos trazem relatos de desejos não saciados e que conhecem um final trágico, contrário ao final feliz sucedido com os amantes de Diálogos do amor. Em razão disso, os cinco contos a seguir revelam os infortúnios suscetíveis àqueles que desconhecem o poder de Eros e que ignoram a capacidade deste sentimento de dominar os amantes e de tornálos impotentes frente ao seu desejo. Em Contos de amor, o poder de Eros utrapassa a esfera privada e se manifesta também na pública, a punição do deus não está voltada apenas para alguns indivíduos mas também para sua cidade. Percebemos que os infortúnios resultantes da interferência de Eros nas situações amorosas dependem do tipo da desonra cometida contra o amor e o desejo que o deus inspirou.

Apesar do destino trágico dos protagonistas, Plutarco acrescenta algumas cenas que tocam o cômico e que nos conduzem a um estilo tragicômico que Capriglione (2007, p. 255) associa ao de Partênio de Niceia, por se tratar de

6 Ésquilo em sua peça Prometeu Cadeeiro, verso 11, revela que Prometeu foi punido por Zeus para que deixasse de ser amigo dos humanos, um filantropo.

7 Sobre o sentido do filantropo e da filantropia em Plutarco, ver FERREIRA, 2008, pp. 71-97. 
uma narrativa em que o leitor não se deleita com o desfecho dos contos. Como já apontamos, este é o maior contraste com o tratado anterior Diálogo do amor, visto que este também apresenta um drama, ao lado de cenas cômicas, que termina com final feliz. O conteúdo dramático de sua narrativa nos remete ao romance grego do período helenístico que tinha a Comédia Nova como modelo, onde os pares amorosos enfrentavam inúmeras adversidades e triunfavam no final pela força do seu amor. No caso de Contos de amor, Plutarco se distancia do estilo anterior para associar-se ao do romance latino de seu tempo, que traz ao leitor episódios mais dramáticos, com amores frustrados, mortes e suicídios.

\section{A tradução}

\section{CONTOS DE AMOR}

771E Em Haliarto ${ }^{8}$, na região da Beócia, havia uma jovem ${ }^{9}$ que se distinguia por sua beleza, de nome Aristocleia; ela era filha de Teófanes.

771F Estráton de Orcômeno e Calístenes de Haliarto pretendiam casar com ela. Estráton era mais rico e um tanto mais tomado de paixão pela virgem; pois aconteceu de um dia vê-la em Lebadeia ${ }^{10}$, enquanto ela se banhava na fonte Hércina ${ }^{11}$; pois ela ia ser uma canéfora ${ }^{12} \mathrm{em}$ honra de Zeus Rei ${ }^{13}$.

772A Mas Calístenes se sobressaia mais; por sua linhagem, era parente da jovem. Teófanes não sabia lidar com a situação, pois temia Estráton que,

8 Haliarto era muito conhecida entre os romanos por ter sido destruída por eles em 171 a.C. A cidade foi visitada por Estrabão que cita um verso de Homero (Ilíada, II, v. 503) para descrever sua densa vegetação e registrar que o rio Mela que atravessava a cidade de Haliarto estava seco em sua época (Geografia, IX, 2, 8). Mas antes disso, Haliarto era famosa entre os gregos por ter sido palco do embate entre espartanos e tebanos em 385 a.C., quando, além da derrota, houve a morte do rei Lisandro.

9 кópๆ (kórē) é uma mocinha que não conhece os prazeres sexuais, a virgem.

10 Cidade que, segundo a descrição de Estrabão (Geografia, IX, 2, 8), estava situada entre Orcômeno e Queroneia.

11 Pausânias elabora uma minuciosa descrição da fonte Hércina em Descrições da Grécia, IX, 39, 1, e nos traz a informação de que ela nasce em uma gruta.

12 Jovem que levava na cabeça um cesto com os preparativos para os sacrifícios.

13 O templo de Zeus Rei e o oráculo de Trofônio estavam localizados em Lebadeia, que também são detalhadamente descritos por Pausânias (Descriçóes da Grécia, IX, 39, 2-4). 
por sua riqueza e linhagem, distinguia-se de quase todos os beócios, e quis confiar a escolha a Trofônio ${ }^{14}$. Estráton, porque havia sido convencido pelos servos da jovem de que ela estava mais inclinada para ele ${ }^{15}$, exigia que a própria pretendida fizesse a escolha. E quando Teófanes perguntou à jovem na presença de todos, e ela se decidiu a favor de Calístenes,

772B logo ficou evidente que Estráton ficara indignado com a desonra; passados dois dias, ele foi até Teófanes e Calístenes por considerar justo preservar a amizade que ele tinha com ambos, ainda que seu casamento the tenha sido negado por inveja ${ }^{16}$ de alguma divindade. E ambos elogiaram o que foi dito, de modo que eles ainda o convidaram para o banquete de bodas. E ele preparou alguns companheiros do povo e um número não pequeno de servos que ficaram espalhados e escondidos no meio deles até o momento em que a virgem, conforme a tradição, foi até a fonte chamada Cissussa ${ }^{17}$ oferecer às Ninfas o sacrifício preliminar ${ }^{18}$,

772C então todos os que estavam na emboscada correram com ele até ela, e ele a capturou. Estráton tinha a virgem em seu poder; e Calístenes, como é natural, agarrou-se a uma parte dela e também os que estavam com ele até que a jovem ficou em suas mãos, e porque eles a puxavam em sentido contrário, ela morreu. Então, Calístenes logo desapareceu, quer por ter cometido suicídio,

14 Filho de Apolo e de Epicasta, Trofônio era o herói da Lebadeia na Beócia, onde estava situado o seu famoso oráculo, dom que herdara de seu pai. Cf. ARISTÓFANES, Nuvens, 508; FILÓSTRATO, Vida de Apolônio, 8, 19; PAUSÂNIAS, Descrições da Grécia, VII, 10,2 e IX, 11, e CÍCERO, Tusculanas, 1, 114.

15 Por meio deste artifício literário, Plutarco deixa entrever que a bela virgem estava apaixonada por Estráton e que seu pai havia lhe forçado a escolher o jovem com o qual tinha laços familiares, como era comum à época. Assim, esta informação subliminar nos mostra como Eros foi desonrado. Outro aspecto interessante é que Plutarco utiliza os servos como informantes, explorando um elemento do romance que são as verdades que circulam nas cozinhas, nos corredores das casas e dos palácios, onde os servos são tratados como seres invisíveis e, ao mesmo tempo, como conhecedores detalhes dos acontecimentos, pois é a partir de suas informações que as ações são tomadas.

16 A inveja de uma divindade é um lugar-comum na literatura grega, por exemplo, Heródoto (Histórias, I, 32) atribui a Sólon a seguinte afirmação: “Creso, eu sei que a divindade é em tudo invejosa e perturbada". Em outra perspectiva, a inveja de um deus também é um lugar-comum na literatura erótica, como pode ser visto em Xenofonte de Éfeso, Efesíacas, III, 2 e V, 1 e em Aquiles Tácio, As aventuras de Leucipe e Clitofonte, III, 23.

17 Kıббó $\sigma \sigma \alpha$ (Kissóessa) significa literalmente "a fonte de Hera". Plutarco conta que esta fonte era conhecida por ter sido o local onde Dioniso se banhara quando recém-nascido. Em razão disso, a água da fonte tinha a cor brilhante do vinho e potável (Vida de Lisandro, XXVIII, 7).

18 No dia anterior ao casamento, a noiva devia fazer oferendas e sacrifícios, o que se denominava

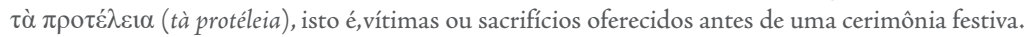


quer por ter partido em exílio da Beócia; e ninguém sabe dizer o que aconteceu. Sob os olhos de todos, Estráton degolou-se sobre a virgem.

Um certo Fídon, que aspirava ao poder sobre os peloponésios, desejava que a cidade dos argivos, a sua pátria,

772D tivesse a hegemonia sobre as restantes, primeiro conspirou contra os coríntios; com o envio de mensageiro, exigiu-lhes mil jovens que se distinguissem em vigor e coragem; e eles lhe enviaram os mil jovens e indicaram Dexandro como seu estratego. E Fídon tinha em mente atacá-los, a fim de que tivesse Corinto mais fraca e tirasse proveito da cidade, pois essa era a fortificação avançada mais conveniente de todo o Peloponeso, e confiou a ação a alguns de seus companheiros. E entre eles estava também Hábron; e porque era hóspede ${ }^{19}$ de Dexandro, contou-lhe sobre a conspiração. E assim os flísios retornaram a salvo a Corinto antes do ataque, e Fídon

772E tentava descobrir quem era o traidor e continuava interrogando com diligência. Por temor, Hábron fugiu para Corinto, pegou sua mulher e servos e ficou em Melisso, uma aldeia do território coríntio; onde também gerou um filho que chamou Melisso, colocou-lhe o nome do lugar. Desse Melisso nasceu um filho chamado Actéon, o mais belo e mais sensato dos de sua idade, do qual muitos se tornaram amantes, de modo especial Árquias, que era da linhagem dos Heraclidas, por ser rico e com destacado poder, era o mais ilustre dos coríntios. Porque não foi capaz de persuadir o jovem, decidiu usar a violência ${ }^{20}$ e raptar o rapaz;

772F então, avançou alegremente para a casa de Melisso com um grande número de amigos e servos e tentou levar o jovem. E quando se colocou contra seu pai e seus amigos, os vizinhos correram para ajudar e puxaram Actéon para

19 Plutarco revela que existia entre as partes um acordo de hospitalidade, de $\xi \varepsilon v i ́ \alpha$ (xenía). Havia entre os gregos as chamadas regras de hospedagem que compreendiam o máximo de respeito ao homem que o recebesse em sua morada. O caso de quebra das regras de hospitalidade mais conhecido é o de Alexandre ou Páris, o que era considerado uma ofensa não somente ao humano, mas também a Zeus Xênio, o deus que regia as normas de hospedagem. Tal costume já aparece em Homero, quando Odisseu chega à ilha dos Feácios e é recebido pelo rei Alcínoo, consultar HOMERO, Odisseia, VI e VII.

$20 \mathrm{O}$ uso da violência é outro lugar-comum na literatura erótica, que ocorre quando o tomado pelo extremo desejo não consegue convencer pelo jogo de sedução, então se vê repelido e usa a força para satisfazer seu desejo. Plutarco conta um episódio semelhante de um general romano que se apaixonou por jovem órfão chamado Dâmon, quando este o rejeitou após tentativas de seduzi-lo com presentes, o general usou a violência (Vida de Címon, I, 3). Há relatos semelhantes em Xenofonte de Éfeso (Efesíacas, IV, 5 e V, 4-5) e Longo (Dáfnis e Cloé, I, 19-20). 
o seu lado, porque foi puxado em sentido contrário, o jovem morreu; e assim eles se afastaram ${ }^{21}$.

773A Melisso levou o cadáver do seu filho até a ágora de Corinto e o exibiu em público, pedindo justiça contra os que praticaram tais coisas; e eles não fizeram outra coisa que sentir pena do homem. Malsucedido, retirou-se e aguardou o festival dos Jogos Ístmicos, e após subir até o templo de Posídon, gritou com força contra os Baquíadas e lembrou a beneficência de seu pai, evocou os deuses e se jogou do rochedo. Não muito depois disso, a seca e a peste tomaram a cidade; e quando os coríntios consultaram o oráculo para que se libertassem dessa situação, o deus respondeu que essa era a ira de Posídon e que não seria abrandada

773B até o momento em que punissem alguém pela morte de Actéon ${ }^{22}$. Após ter sido informado sobre isso, Árquias, pois ele próprio era o embaixador, não retornou para Corinto, navegou até a Sicília e fundou Siracusa ${ }^{23}$. E lá se tornou pai de duas filhas, Ortígia e Siracusa, e foi traiçoeiramente assassinado por Télefo, que era o seu favorito, o que navegou um dia com ele para a Sicília comandando uma nau.

Um homem pobre, cujo nome era Esquédaso, habitava em Leuctras; que é uma aldeia do território de Téspias. Ele tinha duas filhas; elas se chamavam Hipo e Milécia, ou, conforme alguns,

773C Teano e Euxipe. Esquédaso era honesto e cordial com os hóspedes, embora não os recebesse com frequência. Então, quando dois jovens cidadãos espartanos $^{24}$ chegaram à sua casa, ele os recebeu com boa vontade; e eles se apaixonaram pelas virgens, mas foram impedidos de qualquer ousadia pelo

21 O triste destino do jovem também foi contado por Diodoro Sículo (Biblioteca Histórica, VIII, 10) e por Máximo de Tiro (Dissertações filosóficas, XVIII, 1).

22 O conteúdo trágico deste conto nos remete ao episódio de Édipo quando recebe a notícia de que o assassino de Laio deveria ser punido para que Tebas voltasse a ser uma cidade próspera, distante do sofrimento que dominava a cidade; consultar Sófocles, Édipo Rei, vv. 300-461.

23 A história da fundação de Siracusa é contada por Estrabão (Geografia, VI, 2, 4) e Pausânias (Descrições da Grécia, V, 7, 3). Ambos atribuem a Árquias a fundação da cidade e relatam que suas filhas receberam os nomes de suas fundaçôes: Ortígia e Siracusa.

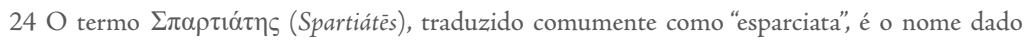
exclusivamente ao cidadão espartano, distinguido por ter nascido em Esparta e ser filho de cidadãos espartanos. Em nossa tradução, optamos por traduzir $\Sigma \pi \alpha \rho \tau \imath$ ótๆ (Spartiátēs) sempre por "cidadão espartano", em lugar de "esparciata". 
caráter nobre de Esquédaso. No dia seguinte, partiram para Píton ${ }^{25}$; pois esse caminho já estava traçado para eles; e depois de consultar o deus sobre o que precisavam, retornaram para casa, e quando passavam pela Beócia, retornaram à casa de Esquédaso. E ele por acaso não estava em Leuctras, mas as suas filhas que, pela educação costumeira dele ${ }^{26}$,

773D receberam os hóspedes. E como eles encontraram as jovens sozinhas, violentaram-nas; e ao vê-las em extrema indignação pela violação, eles as mataram; então as jogaram em um poço e se livraram delas. Quando Esquédaso retornou, não viu as jovens e encontrou todas as coisas que foram deixadas intactas, ficou perplexo com o fato até que sua cadela começou a latir, e porque corria muitas vezes em sua direção e retornava para o poço, imaginou o que poderia ser, então retirou os cadáveres das suas filhas dali. E depois de ter sido informado por vizinhos de que eles tinham visto no dia

773E anterior os lacedemônios hospedados na véspera entrarem em sua casa, compreendeu a ação daqueles, porque também na véspera eles haviam elogiado continuamente as virgens, disseram que seriam bem-aventurados os que as desposassem ${ }^{27}$. Partiu para a Lacedemônia para se encontrar com os éforos; quando estava na Argólida, ao cair da noite, foi para um albergue; e no mesmo lugar havia também outro ancião nascido em Oreu, cidade de Hestieia; porque estava se lamentando e lançando imprecaçóes contra os lacedemônios, Esquédaso quis saber qual mal havia sofrido dos lacedemônios. E ele lhe contou que era um súdito de Esparta e que

773F Aristodemo, enviado a Oreu pelos lacedemônios como harmosta, havia mostrado muita crueldade e transgressão. "Tomado de amor de amor pelo meu filho", ele disse, "uma vez que não foi capaz de persuadi-lo, tentou

25 Antigo nome de Delfos. Píton era o nome da serpente que morava aos pés do Monte Parnaso e que também tinha dons divinatórios, Apolo a matou com suas flechas para fundar seu santuário e instituir o seu oráculo.

$26 \mathrm{O}$ uso do termo $\dot{\alpha} \gamma \omega \gamma \eta ́$ (agogé) mostra que ele era de origem espartana, pois este era o nome dado à educação espartana. Assim, o rigor de sua educação fazia com que seu pai tivesse o total controle de seus atos.

27 Plutarco nos mostra com isso a resistência do pai em permitir que os rapazes cortejassem suas as filhas, o castigo dele foi a perda delas e os jovens forma punidos por não terem obtido a graça das donzelas. Segundo o nosso autor, quando a relação sexual não é regida por Eros, a "graça é

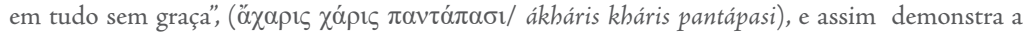
importante participação do deus no ato sexual do casal, visto que a amizade estimulada por essa divindade é que propicia a mulher conceder ao homem a "graça" kháris ( $\chi \alpha ́ \rho ı \varsigma)$, conforme Plutarco nos esclarece neste excerto: "[Eros] usa a amizade para alcançar a graça. Graça, Protógenes, é a concessão feminina dada ao varão, assim chamada pelos antigos." (PLUTARCO, Diálogo do Amor, 751D). 
usar a violência e raptá-lo da palestra; quando foi impedido pelo professor de ginástica e por muitos jovens que vieram em seu socorro, Aristodemo afastouse imediatamente; e no dia seguinte, depois de carregar uma trirreme, raptou o rapaz, navegou para o outro lado de Oreu e tentou violentá-lo, porque não consentiu, ele o

774A degolou. E depois de ter retornado a Oreu, fartou-se em um banquete. E ele disse "eu fui informado sobre o que foi feito, sepultei o seu cadáver, dirigi-me a Esparta e me encontrei com os éforos; mas eles não me deram importância." Esquédaso, ao ouvir isso ficou desanimado, e suspeitou que os cidadãos espartanos também não the dariam qualquer importância; e por sua parte contou a sua desgraça ao estrangeiro; e este o advertiu para que não se encontrasse com os éforos, mas que retornasse para a Beócia e erigisse o túmulo de suas filhas. E mesmo assim Esquédaso não se convenceu, mas partiu para Esparta

774B e foi se encontrar com os éforos; porque nenhum deles lhe deu atenção, foi até os reis, depois deles, chorou se aproximando de cada um dos populares. Como não atingia mais o seu objetivo, caminhou pela cidade estendendo ambas as mãos para ${ }^{28} \mathrm{Hélio}^{29}$, logo batendo na terra, evocou as Erínias ${ }^{30} \mathrm{e}$ finalmente tirou sua vida. Mais tarde, os lacedemônios foram punidos; pois, uma vez que dominavam todos os helenos e haviam capturado as cidades guarnecidas, o tebano Epaminondas primeiro degolou uma guarnição de sua cidade $^{31}$; e quando os lacedemônios realizaram uma guerra por causa dele,

774C os tebanos foram até ele em Leuctras, uma vez que consideravam o seu território de bom augúrio, porque também ali eles tinham sido libertos; foi quando Antífron, condenado ao exílio por Esténelo, veio para a cidade dos tebanos, lá encontrou os calcídios sujeitos a tributos e, ao matar Calcodonte, o rei dos eubeus, interrompeu o pagamento dos tributos. E sobreveio uma completa derrota aos lacedemônios que aconteceu nos arredores do túmulo das filhas de Esquédaso. E contam que antes da batalha Pelópidas, um dos estrategos do exército tebano, por alguns sinais ruis dos oráculos consultados,

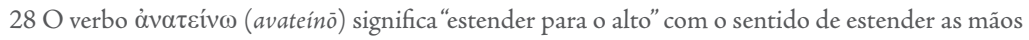
como suplicante.

29 Hélio é conhecido por ser o deus que tudo vê, considerado o olho do mundo.

30 Homero as apresenta como divindades cuja função principal é a vingança de um crime, que castigam principalmente os crimes contra a família, consultar: HOMERO, Ilíada, IX, v. 571; XIX, v. 87.

31 Graças ao empenho e ao engenho militar de Pelópidas, não de Epaminondas, Tebas libertouse de Esparta em 379 a.C., conforme vemos em Xenofonte (Helênicas, V, 4 1-12) e em Plutarco (Vida de Pelópidas, IX, 17, 3 e 19, 3). 
estava perturbado, mas recebeu Esquédaso em sonhos que o exortou a ter confiança;

774D pois os lacedemônios estavam indo a Leuctras para pagar sua pena a ele e a suas filhas; e ele o instruiu a um dia antes de se encontrar com os lacedemônios degolar em sacrifício um potro branco à disposição junto ao túmulo das virgens. Enquanto os lacedemônios ainda estavam em uma expedição militar contra a Tégea, Pelópidas enviou homens a Leuctras para que investigassem a respeito desse túmulo, e depois de ter sido informado pelos locais, ficou confiante, conduziu seu exército e venceu ${ }^{32}$.

\section{4}

Foco era um beócio de nascimento, pois era de Glissas, e pai de Calírroe, que se distinguia por sua beleza e prudência.

774E Trinta jovens mais ilustres da Beócia pretendiam casar com ela; e Foco adiava por diferentes motivos o seu casamento, porque temia sofrer algum tipo de violência; finalmente, pela insistência daqueles, julgou digno que a escolha fosse feita pelo Pítio ${ }^{33}$. E eles ficaram indignados com o seu argumento, avançaram contra Foco e o mataram; nesse tumulto, a virgem fugiu e se lançou pelo território enquanto os jovens a perseguiam. Ela encontrou uns agricultores que amontoavam a colheita e também encontrou neles a sua salvação; pois os agricultores a esconderam no meio do trigo. E assim os seus perseguidores passaram ao largo dela;

774F e ela, depois de ter se salvado, aguardou o festival das Pambeócias ${ }^{34}$, e então foi para Coroneia, sentou-se como suplicante no altar de Atena Itônia, contou-lhe o crime dos seus pretendentes e lhe indicou o nome e a pátria de cada um deles. Então os beócios tiveram pena dela e se irritaram profundamente com os jovens; e eles foram informados que os jovens tinham fugido para Orcômeno. Como os orcomênios

775A não os receberam, eles se dirigiram a Hípota; uma aldeia situada junto ao Hélicon, entre Tisbe e Coroneia; e estes os receberam. Em seguida, os tebanos enviaram homens para reclamar os assassinos de Foco; porque

32 Plutarco registra na Vida de Pelópidas (XXIII, 6) que o general tebano dispunha apenas de trezentos soldados, o que nos faz lembrar de Leônidas e os 300 espartanos da guarda rela que o acompanharam na célebre Batalha das Termópilas.

33 Consultar o oráculo de Apolo, o deus recebia o epíteto de Pítio.

34 Festival que reunia todos os beócios da Confederação Beócia para cultuar Atena Itônia em Coroneia, conforme registra Estrabão em Geografia (IX, 2, 29). 
eles não os entregaram, realizaram uma expedição militar com os demais beócios comandada por Fedo, que então detinha o poder sobre os tebanos; depois de terem cercado a aldeia, que estava fortificada, os que estavam dentro dela foram vencidos pela sede, eles a capturaram e queimaram os assassinos; e os que ficaram na aldeia foram escravizados; e depois de terem destruídos suas muralhas e casas, dividiram o território entre os tisbeus e os coroneus. $\mathrm{E}$ contam que uma noite,

775B antes da tomada de Hípota, ouviram muitas vezes a voz de alguém vinda do Hélicon dizendo "estou aqui"; e que os trinta pretendentes reconheceram esta voz, que era a de Foco. E no dia em que foram apedrejados até a morte, contam que escorreu açafrão do túmulo do ancião em Glissas; e que a Fedo, arconte e estratego dos tebanos, quando retornava da batalha, foi anunciado o nascimento de sua filha, o que considerou um bom augúrio e ele a chamou Nicóstrata ${ }^{35}$.

Alcipo era lacedemônio de nascimento; casado com Damócrita, tornou-se pai de duas filhas; porque aconselhava

775C a cidade do melhor modo e fazia o que os lacedemônios precisavam, ele foi invejado por seus adversários políticos, que então apresentaram falsas acusações aos éforos, alegando que Alcipo queria derrubar as leis, e conduziram o homem ao exílio. Ele saiu de Esparta, e a sua esposa Damócrita quis seguir seu marido acompanhada de suas filhas, mas seus bens também foram confiscados para que as jovens não tivessem recursos para o dote. Visto que, ainda assim, alguns pretendiam casar com as jovens, pela excelência de seu pai, os inimigos impediram por meio de um decreto

775D que esses pretendentes casassem com as jovens, alegando que sua mãe Damócrita implorou muitas vezes para que suas filhas imediatamente gerassem filhos que se tornassem vingadores da morte de seu pai. Pressionada por todos os lados, Damócrita aguardou uma festa pública na qual estavam mulheres e virgens, servos e crianças, enquanto as que tinham um marido em um cargo importante celebravam a festa entre si; e depois de cingir a espada a ela, foi com suas filhas à noite para o templo,

775E onde aguardou o momento em que todas celebravam os mistérios no salão; e quando trancaram as entradas, empilhou muita lenha junto às portas

35 O nome da jovem significa: vencedora de exércitos. Na Vida de Alexandre (III, 9), Plutarco afirma que era um sinal de bom augúrio nascer no dia de uma vitória na guerra. 
(a que havia sido preparada para o sacrifício da festa) e ateou fogo. Quando os homens correram em seu socorro, Damócrita cortou a garganta de suas filhas e a sua própria sobre elas. E os lacedemônios não sabendo como tolerariam isso em seu peito arremessaram os corpos das filhas de Damócrita para fora dos limites do seu território ${ }^{36}$. Em razão disso, porque o deus ficou irado, contam a história de que sobreveio aos lacedemônios um terremoto ${ }^{37}$.

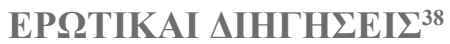

A.

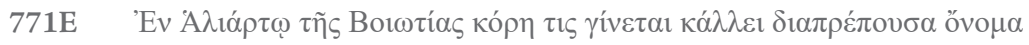

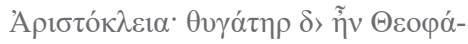

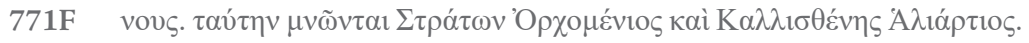

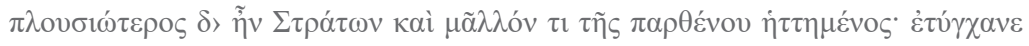

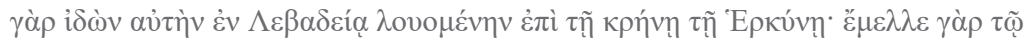

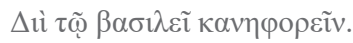

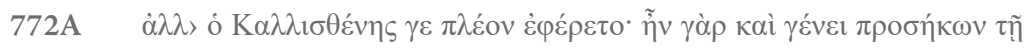

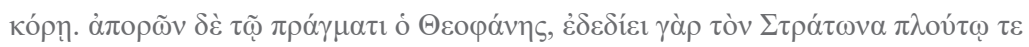

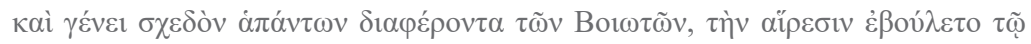

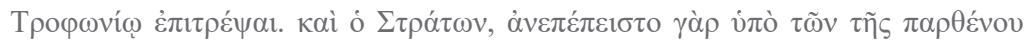

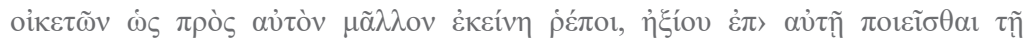

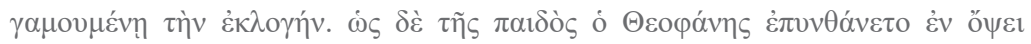

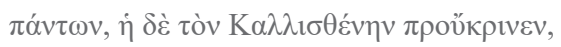

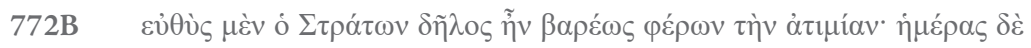

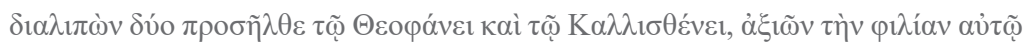

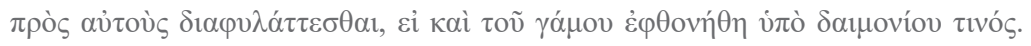

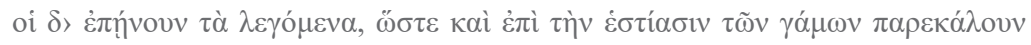

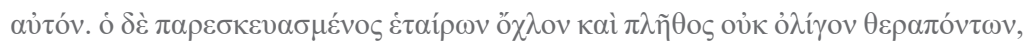

$36 \mathrm{O}$ ato dos lacedemônios representa uma grande insolência, pois retirou dessas mulheres o direito de serem enterradas em solo pátrio, uma questão bastante discutida na peça Antígona, de Sófocles.

37 Trata-se do grande terremoto que abalou Esparta em 464 a.C. e que os espartanos consideravam como um castigo divino, conforme vemos em Tucídides (História da Guerra do Peloponeso), I, 101 e 128, 1, em Diodoro Sículo (Biblioteca Histórica, XI, 63), em Plutarco (Vida de Címon, XVI, 4-5) e Pausânias (Descrições da Grécia, IV, 24, 6).

38 Texto grego de Plutarchi moralia, vol. 4. Edited by C. Hubert. Leipzig: Teubner, 1971. 


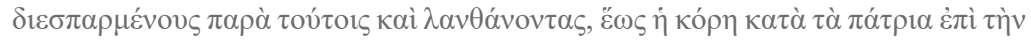

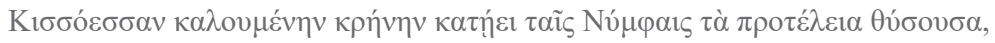

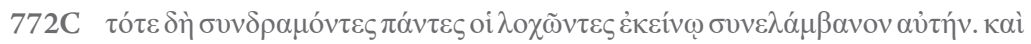

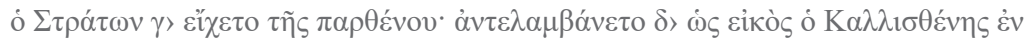

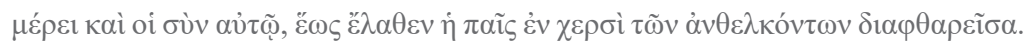

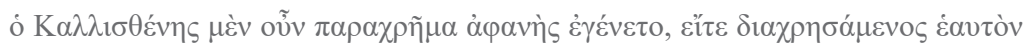

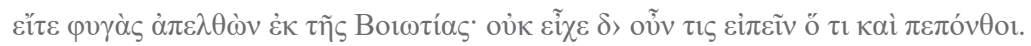
ó $\delta \dot{\varepsilon} \Sigma \tau \rho \alpha ́ \tau \omega \nu ~ \varphi \alpha v \varepsilon \rho \tilde{\omega} \zeta \dot{\varepsilon} \pi 1 \kappa \alpha \tau \varepsilon \dot{\varepsilon} \sigma \varphi \alpha \xi \varepsilon v \dot{\varepsilon} \alpha v \tau o ̀ v \tau \tilde{n} \pi \alpha \rho \theta \dot{\varepsilon} v \omega$.

B.

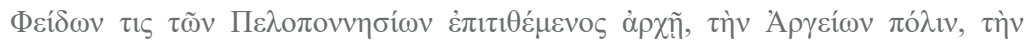

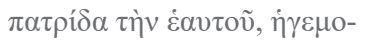

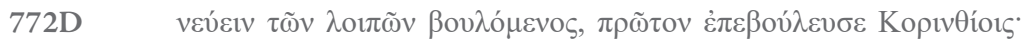

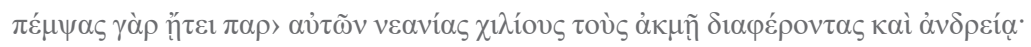

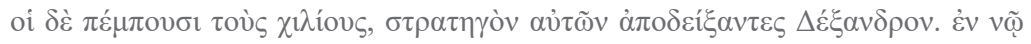

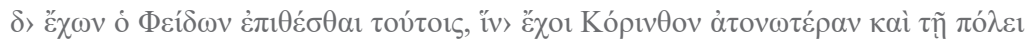

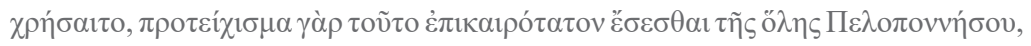

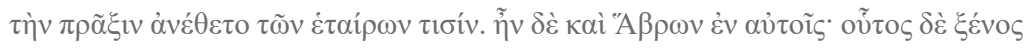

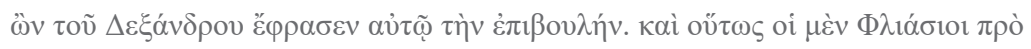

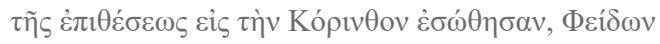

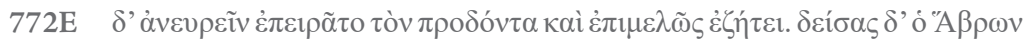

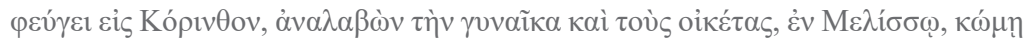

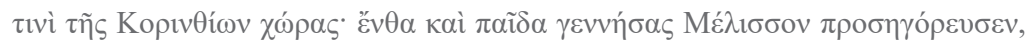

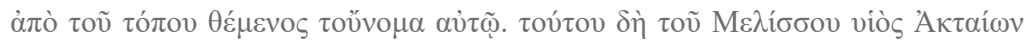

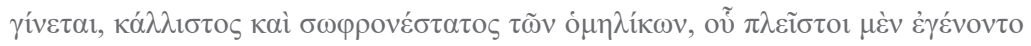

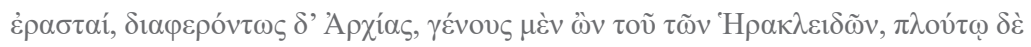

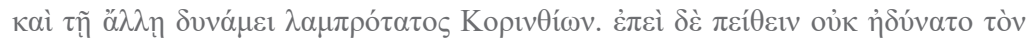

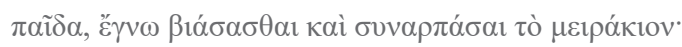

772F غ̇ं

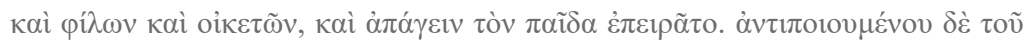

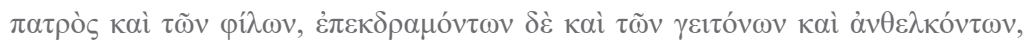

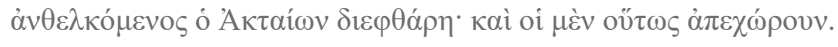

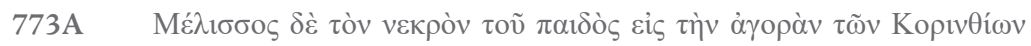

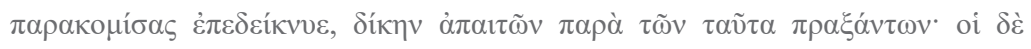

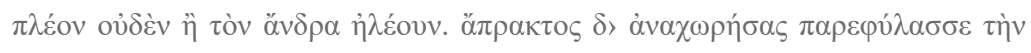

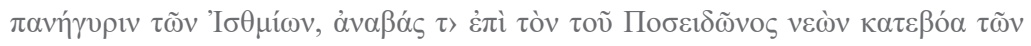




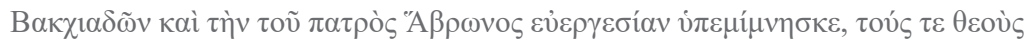

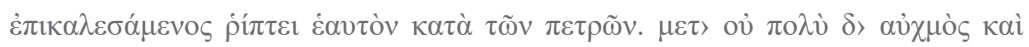

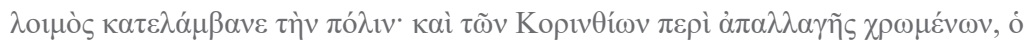

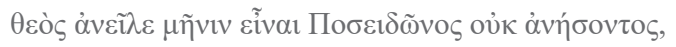

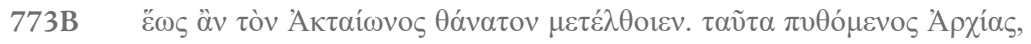

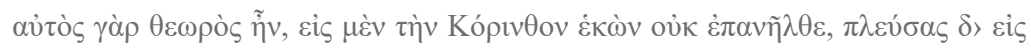

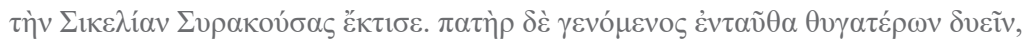

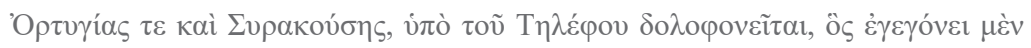

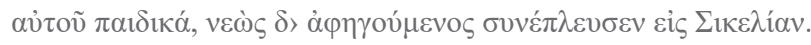

\section{$\Gamma$.}

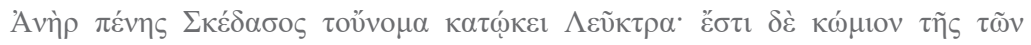

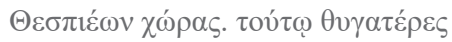

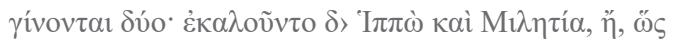

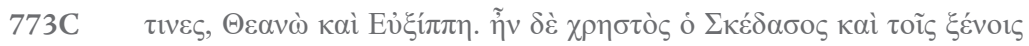

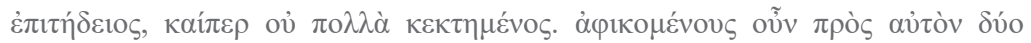

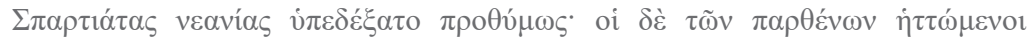

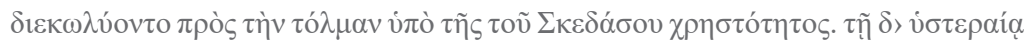

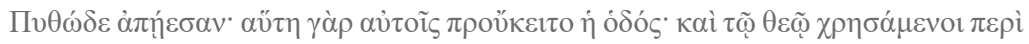

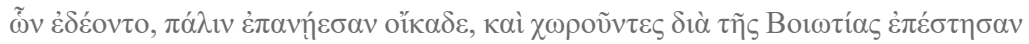

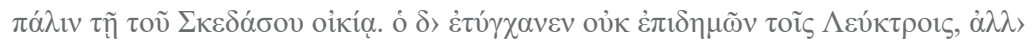

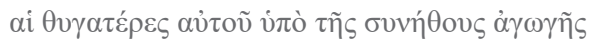

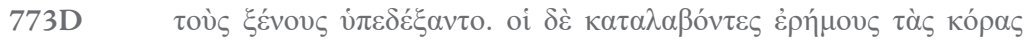

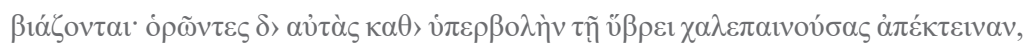

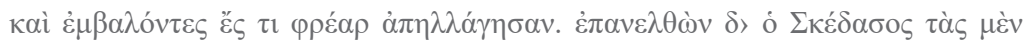

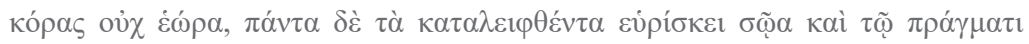

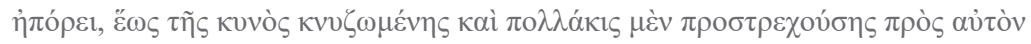

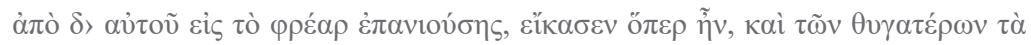

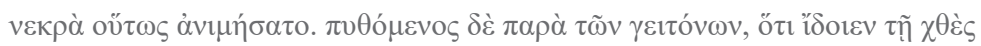

773E ं

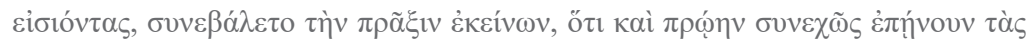

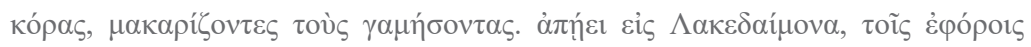

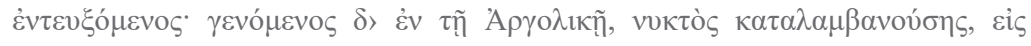

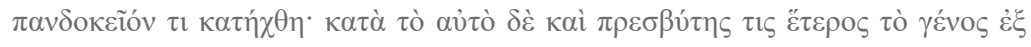

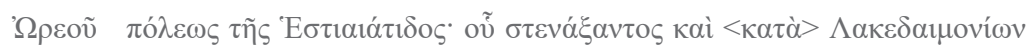

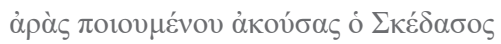




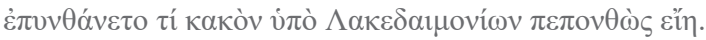

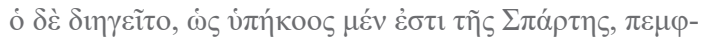

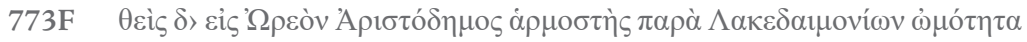

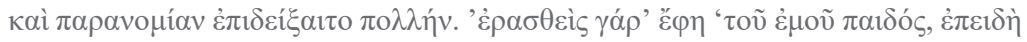

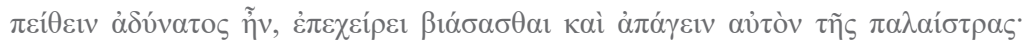

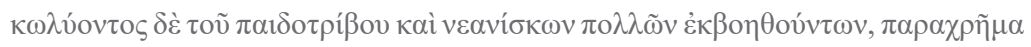

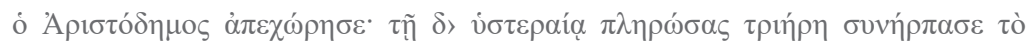

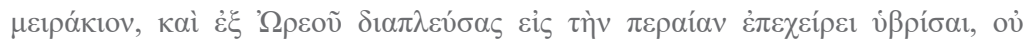

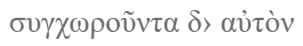

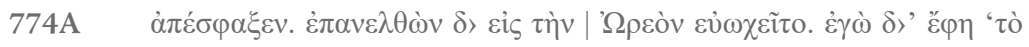

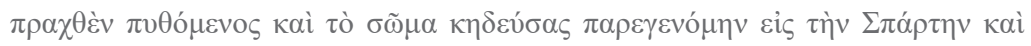

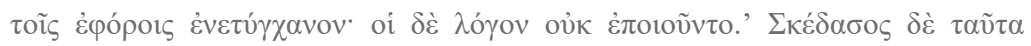

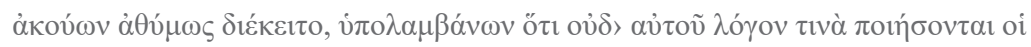

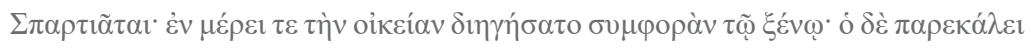

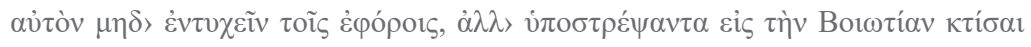

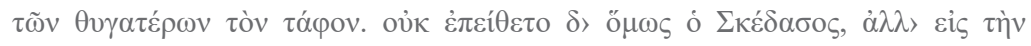
$\Sigma \pi \alpha ́ \rho \tau \eta v \dot{\alpha} \varphi ı \kappa o ́ \mu \varepsilon v o \varsigma$

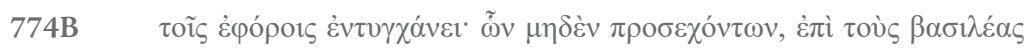

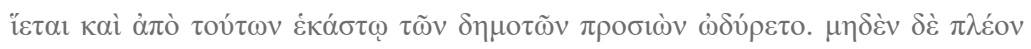

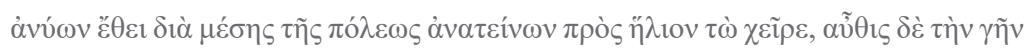

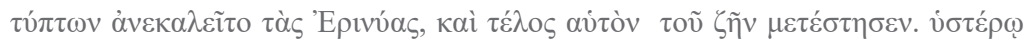

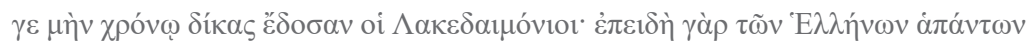

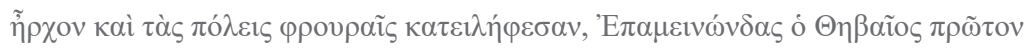

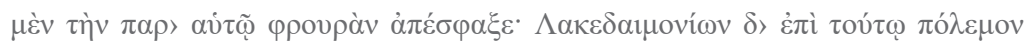
$\dot{\varepsilon} \xi \varepsilon v \varepsilon \gamma-$

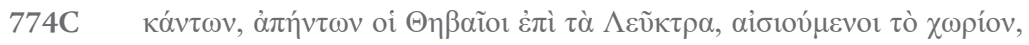

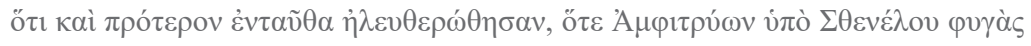

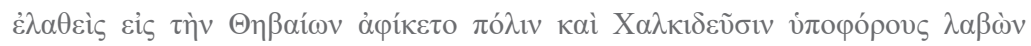

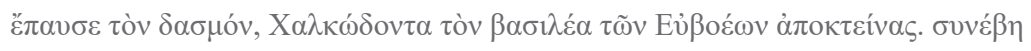

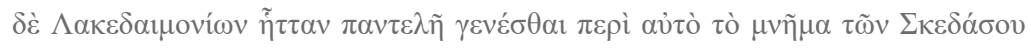

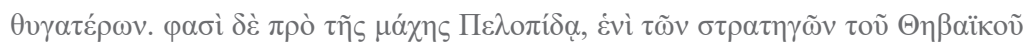

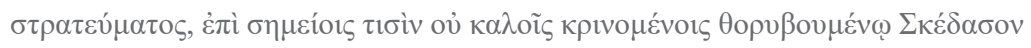

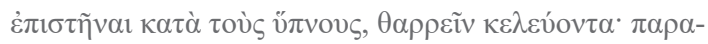

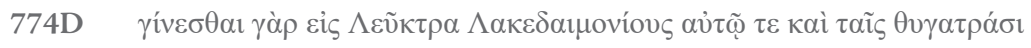

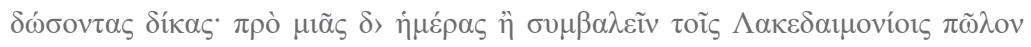

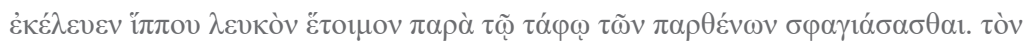

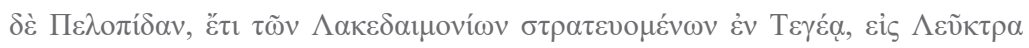




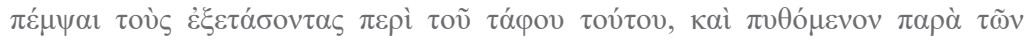

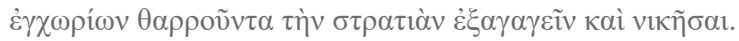

$\Delta$.

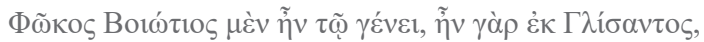

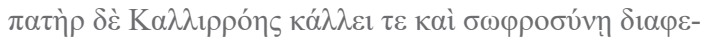

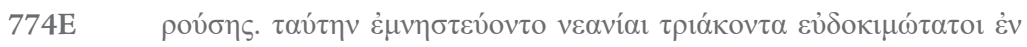

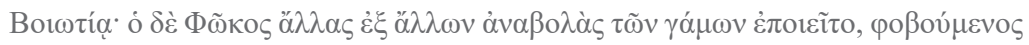

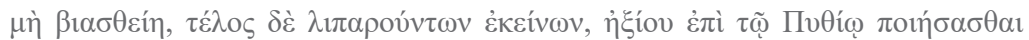

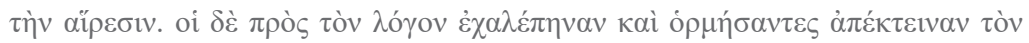

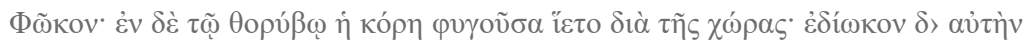

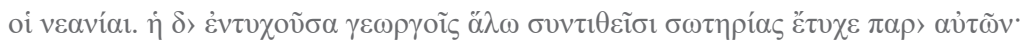

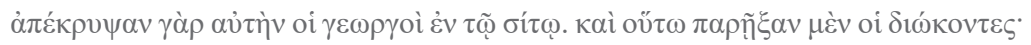
$\dot{\eta} \delta \dot{\varepsilon}$

774F

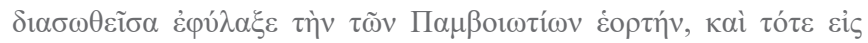

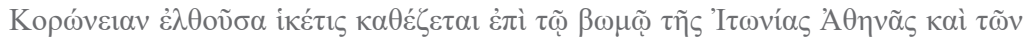

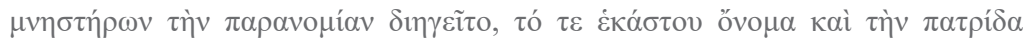

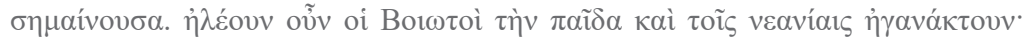

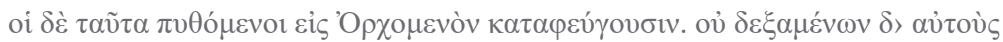

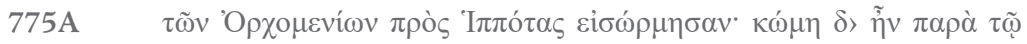

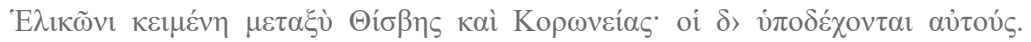

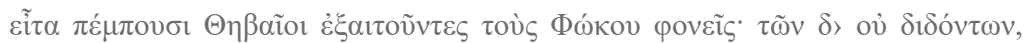

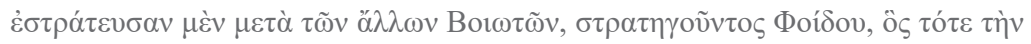

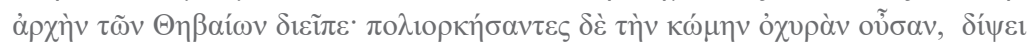

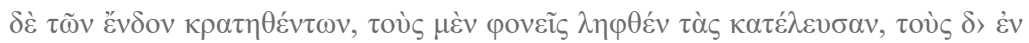

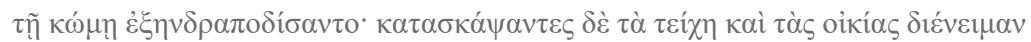

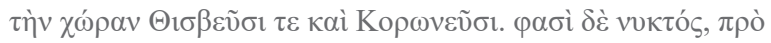

775B

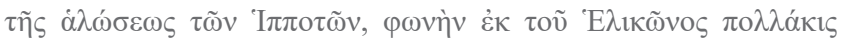

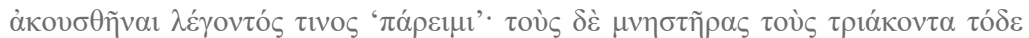
$\tau$

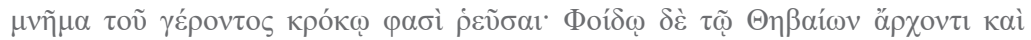

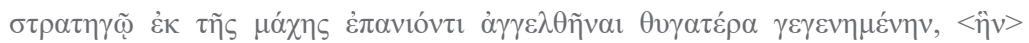

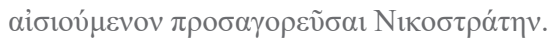

\section{E.}

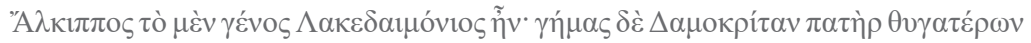

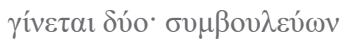


775C

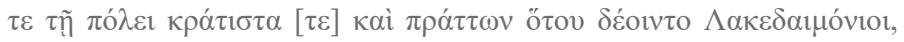

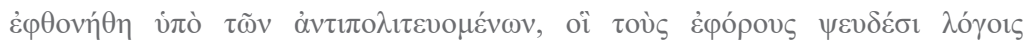
$\pi \alpha \rho \alpha \gamma \alpha \gamma o ́ v \tau \varepsilon \varsigma, ~ \omega \varsigma \varsigma ~ \tau o v ̃ ~ A \lambda \kappa i ́ \pi \pi o v ~ \beta o v \lambda o \mu \varepsilon ́ v o v ~ \tau o v ̀ \varsigma ~ v o ́ \mu o v \varsigma ~ \kappa \alpha \tau \alpha \lambda \tilde{\sigma} \sigma \alpha 1, ~ \varphi v \gamma \tilde{n}$

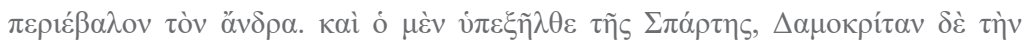

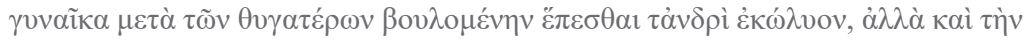

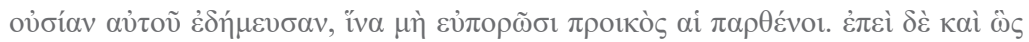

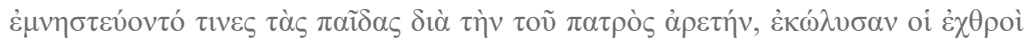

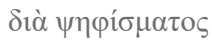

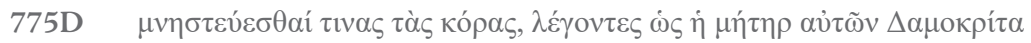

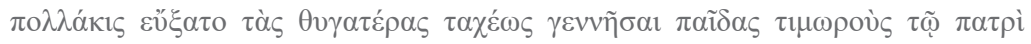

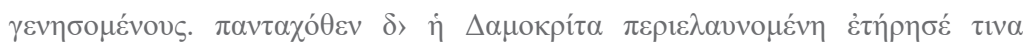

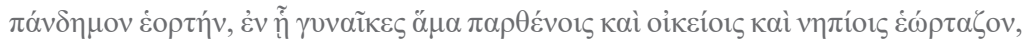

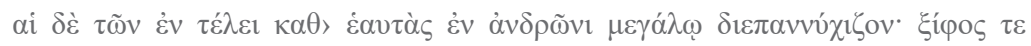
vं

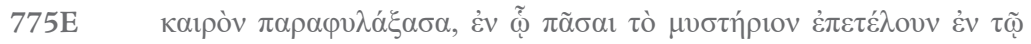

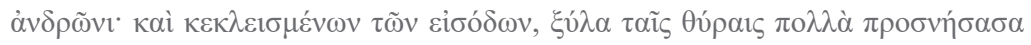

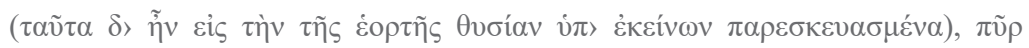

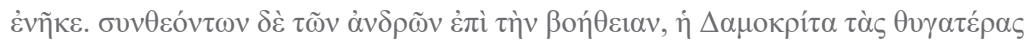

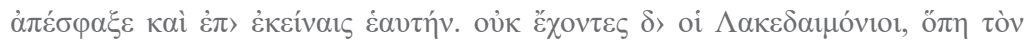

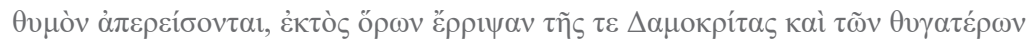

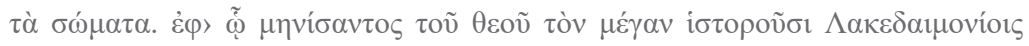

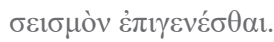




\section{REFERÊNCIAS}

Fontes

ÉSQUILO. Prometeu Cadeeiro. In: Tragédias. Estudo e Tradução de Jaa Torrano. Edição bilíngue. São Paulo, Iluminuras, 2009.

PLUTARCO. Da malícia de Heródoto. Edição bilíngue. Estudo, tradução e notas de Maria Aparecida de Oliveira Silva. São Paulo, Edusp, 2013.

PLUTARCO. Diálogo do amor. Edição bilíngue. Tradução, introdução e notas de Maria Aparecida de Oliveira Silva. São Paulo, Martin Claret, 2015.

PLUTARCO. Narrazzioni d'amore. A cura di Giuseppe Giangrande. Napoli: D’Auria M., 1991.

\section{Bibliografia}

CAPRIGLIONE, Jolanda C. Narrazzione senźamore. In: NIETO, Jesús $M^{a}$; LÓPEZ, Raúl (ed.). El amor en Plutarco. IX Simposio Internacional de la Sociedad Española de Plutarquistas. León: Universidad de León - Secretariado de Publicaciones, 2007, pp. 255-263.

FERREIRA, José R. O Doce Afago da Philantropia. In: SOARES, Carmen, FERREIRA, José R. e FIALHO, Maria do Céu (eds.) Ética e Paideia em Plutarco. Coimbra, Centro de Estudos Clássicos e Humanísticos, 2008, pp.71-97.

FLACELIÈRE, Robert. Notice. In: PLUTARQUE. Dialogue sur l'Amour.

Oeuvres Morales. Tome X. Paris, Les Belles Lettres, 2003, pp. 3-46.

FLACELIÈRE, Robert \& IRIGOIN, Jean. Introduction générale. In: PLUTARQUE. Oeuvres Morales. Tome I. Paris, Les Belles Lettres, 1987, pp. VIICCCXVIII.

JONES, Christopher P. Towards a Chronology of Plutarch's Works. The Journal of Roman Studies, vol. 56, parts 1 and 2, 1966, pp. 61-74.

LAMBERTON, Robert. Plutarch. New Haven/London, Yale University Press, 2001.

SILVA, M. A. O. Plutarco historiador: análise das biografias espartanas. São Paulo: Edusp, 2006.

VOLKMANN, R. Ueber die Echtheit von Plutarchs zweiter Rede von Alexanders Glück oder Verdienst. Klassische Philologie. CI, 1870, pp. 816-821.

ZIEGLER, Konrat. Plutarchos von Chaironeia. Paulys Real-Encyclopädie der Classischen Altertumwissenschaft. Stuttgart, Verlag, 1951, cols. 636-962. 